\title{
The Structural and Cultural Role to the Family House Hold of Self-employment Woman in Malang Regency, Indonesia
}

\author{
Darsono Wisadirana $^{1}$ \\ ${ }^{1}$ University of Brawijaya, Indonesia \\ Correspondence: Darsono Wisadirana, MS, University of Brawijaya, Indonesia.
}

Received: January 16, 2017

Accepted: February 15, 2017

Available online: February 22, 2017

doi:10.11114/ijsss.v5i3.2153

URL: https://doi.org/10.11114/ijsss.v5i3.2153

\begin{abstract}
Family is also the first pillar to meet the social, economic, psychological and culture aspect to the individual. In prostitution aspect, someone who decides to be self-employment woman can be known from the socialization style in the family. Because of that, it is important to know about family role and function in solving prostitution problem. Therefore, the problem is how the structural and cultural role is occupied by each family member in the daily life of house hold.

This research aims to analyze the process of someone to be self-employment woman from the aspect of instilling the moral and norm by each family member, analyze the social relation in the family, one of whose member is a self-employment woman, and analyze the function which is acted by each member to the self-employment woman. This research used Functional Imperatives Talcott Parson theory to analyze the structural and cultural role of self-employment woman's family. The methodology used in this case was qualitative research design.

The result of the research shows the economic factor. Besides the factor of young marriage culture which causes the divorce. After divorce, the women start to work as self-employment woman. Lacking of the education awareness can be one of the causes in increasing the number of self-employment woman.

Lacking of communication among the family can cause the parents are not able to keep the children from social deviation. Social deviation which has been occupied for long time can be human habit and common activity in society.
\end{abstract}

Keywords: structural role, cultural role, family

\section{Introduction}

According to the declaration of Millennium Development Goals (MDGs), one of the points is attacking HIV/AIDS, malaria, and other infectious diseases. Especially about HIV/AIDS, one of whose cause is constantly having sex with the different couple that is usually done by self-employment woman. Minimizing this action becomes the important thing to do as the responsibility from the declaration of MDGs.

Self-employment woman is the new name for the woman who works as a prostitute. The purpose is to make the prostitute able to live normally with the lawful income instead of being the prostitute again.

Many efforts done to overcome the increasing of prostitution yet the prostitution problem is still working up to now. It is interesting topic to observe deeply as the research from the different aspects. One of them is by seeing the prostitution practice from the function of family as the first of education foundation for someone.

In this case, the existence of self-employment woman constantly does not become the concern of the family. Family is not the parts of problem causes that happen to one of family members. In this case, self-employment woman finally can fall into the prostitution as well. From that case, it is very important to ask about the existence of family function so one of their families can fall into the prostitution. Family protection and defense do not work well can be one of the causes. The deviations which are done by the members of family should be a mirroring about family function arrangement which should be able to avoid this deviation happens.

Another research which has the title Parenting Style, teenager interaction and father satisfaction states that almost all male and female teen admit that their parents used democratic parenting style. For boys, the interaction working shows that the communication work between the father and the youth within 0-5 minute per day. While the communication 
between damsels allocated within 16-30 minutes per day. (Krisnatuti, Putri, 2012). It shows that the protection to the daughters is higher than the sons moreover when they are growing up to be teenager.

From that case, it is important to know more, how far the family role and function can avoid the prostitution that can't be solved yet. In other cases, some of the family lead one of their member to fall into the prostitution instead. While the other family does not know that their family member fall into the deceit that cause them to be self-employment woman. Therefore this research will observe deeply about how the family functions for self-employment woman.

\subsection{Research Focuses}

Based on the background above, this research aims to know how the structural and cultural role in the family that makes one of the family member become self-employment women. It is presented the formulation of the problem namely:

1) How is the process of family member to be self-employment woman?

2) How is the social relation between family member and self-employment woman?

3) How are the function and role which are occupied by each family member?

\subsection{Objectives of Study}

This research will tell more about the structural and cultural role to the family house hold of self-employment woman in Ngantang district Malang regency, the study is directed to the following purposes:

1) To analyze the process of family member to be self-employment woman from the aspect of instilling the norm, moral, and value by the family

2) To analyze the social relation in the family, one of whose members becomes self-employment woman

3) To analyze the functions which are occupied by each family member toward self-employment woman

\section{Review of Related Literature}

Functional Imperatives Talcott Parson Theory

According to Talcott Parson, functional system is an activity that leads to meet one or some system necessity (Ritzer. 2005). Parson divides function to be four, named AGIL:

1. Adaptation .

2. Goal Attainment.

3. Integration.

4. Latens.

In the case of self-employment woman has cause and effect relation between the family function and a self-employment woman. Both of them have relation that can't be separated according to Parson. Family gives the first socialization and protection toward their member and have significant role to the members' growth. Moreover in the case of deviations, the family function is really needed to avoid negativity toward their members.

\subsection{Structural Role}

Family structure consists of a father that has role as a father for the children and a husband for the wife, also a mother that has role as a mother for the children and a wife for the husband, and the children that occupy their function.

The role of father is as a livelihood earner, an educator, a protector, a leader of family, a member of family from his social group, and also as a member of society from his environment. While the role of mother is managing the house hold, the educator of the children protector, as one of the group from her social role, and also as a member of society from her environment. Beside that, a mother can have a role to be livelihood earner to help the husband. And the role of children is to occupy psycho-social according to the grade of their growth, including psychic, mental, social, and spiritual as well.

\subsection{Cultural Role}

Based on the cultural, we are in era where the women have the same role with the men in social aspect. If in the family, the woman take the role as a mother and a wife that has duty to manage the house hold. Now, many women had the role to earn money for the family. This transformation of value increases. According to Abdullah (2011) states that labor force Participation Rate (TPAK) in 1990 is 38,74\%. While in 2014 labor force Participation Rate (TPAK) is 50,22 \%. The number that rapidly develops makes the role to manage the house hold is going to be awkward for the woman. In other sides, having the role to manage the house hold, in other sides also has the role to earn money. So the effect is the children do not get the good education. In this case, the children do not get the intention and control in social deviation including sex education, and etc. 


\subsection{Family}

Generally, family has many functions. According to Zastrow (1999), the family has five fungus:

1. The function of family for regeneration or getting heredity

2. The function of family to look after the children in order to grow well.

3. The function to socialize the culture, norm, language value to the family.

4. The function to manage sexual action.

5. The function to give the affection and love for the family. Inharmonic family happened because the members of family are not able to share the love and affection to other member of family.

\subsection{Self-employment Woman}

Self-employment woman is the new name for the woman who works as a prostitute. Self-employment woman is known and used after the closing of some localization in some areas in Indonesia. Self-employment woman is introduced by the social minister to change the name prostitution (Female Commercial Sex) to be self-employment women in order to rise the degree of ex prostitute and to make them able to survive by earning the lawful money.

\section{Research Method}

This research used qualitative research. The research was conducted in Ngantang district, Malang regency. Ngantang was chosen because there are many self-employment women there. Beside of that, there is social deviation that has been considered something normal by the society around. It becomes the common thing for the society around.

This research chose the informant by using purposive technique or intentionally. The choosing of informant is done with the purpose to help the researcher to get much information in the short time due to the informant was utilized to speak, share, discuss and compare an event found by other subjects. The informants in this research are the subject itself or the family of self-employment woman also the researcher will interview the self-employment woman. The data takes was primer data and secondary data.

This research used 3 kinds of data collecting method. They are observation, deeply interview and documentation. Data analysis technique used interactive model data analysis from Miles and Huberman. The data got then collected systematically. Start from interview, editing, clarifying, and reducing, then serving the data and concluding the data. Data analysis technique in this research used interactive analysis model (Miles and Huberman, 1984, 15-21 ). The accuracy of quantitative research usually happens at the time when data collecting process and data interpret- analysis. In this research, the researcher used the data accuracy technique such:

1. Reset subject competence

2. Trust worthiness

a. Authenticity

b. Triangulation Sources

\section{The History of Self-Employment Woman (WKM)}

Somebody has many reasons to be a self-employment woman (WKM). The dominant factor is the economic factor. The economic factor can be the common reason that is told by the self-employment woman (WKM). So, this one can be a habit or something normal for the self-employment woman (WKM) to do prostitution. The factors that encourage the people fall into the prostitution are economic, sociologies, and psychologies factor. The economic factor, lacing of the income and the daily need increase rapidly. Therefore, prostitution is considered as the instant solution. Sociologies factor, about the development and social-culture changes so fast, the bad social relation, the pragmatic society, and the decreasing social values. Many family members are not able to adapt with the era development. They are alienated by the society. The prostitution is considered as the alternative to go out from the alienation. Psychology factor, the low personality and easy to be influenced, the low morality cause the difficulty to differentiate the goodness and the badness, the truth and the false, lawful and unlawful. Those can cause somebody fall into the prostitution. As AB (Informant) said:

If the father was never told. But in an economy like this, I realized myself so I never cheat, but not my will. Due to my tight economy. So there used to be my stall but bankrupt since my father left. Then my license at my husband. There are people looking for work in Sabah (Malaysia). Precisely in Keminau (Malaysia). In agreement not fit at his job. I just known, it was not an agent but a realtor. After that I was with my friend the same age Tulungagung (one of regency in Indonesia) I was her age he came and told me there was good in working in the restaurant then a big salary was substantially tasty. (Interview with AB, WKM) 
Besides that, there is environment factor that make someone fall into the prostitution. How the structure influences the growth of children and gives influence toward the attitude that was acted by that one. In the research location found that the society there has the culture of young marriage. Even the family has the initiative that the marriage will be carried out in the very young age. As BC (informant) said:

My son there 3. My son is getting married and fail now works. My children who make a living with his father. Now 16 years old. Age 14 years are married. Rather than long betrothed soon married. Elementary school. Do not want to continue the junior high school when I did not want to buy a motorcycle. Married three months. Yes so young married young. Now in Kalimantan is already 6 months. Come with whom I did not know there. But already home 2 times and take the money. (Interview with BC. The mother of WKM)

Another factor, somebody falls into the prostitution because of young marriage. From psychologies aspect, the young age has not been supported by the well-developed mindset and attitude. The parents that determine the marriage should consider the psychologies of the children. The well-developed mindset and attitude can be achieved by the go of age. But the young marriage culture in the society considers that the children have been ready to get married even there are many prove that there many couple of young marriage are failed.

The culture of young married in the society encourages them to marry their children soon. The reason is to avoid the children fall into the juvenile delinquency and free sex. But, the self-employment woman in the research place shows the differences instead. In fact, the young marriage causes the traumatic to get married and the traumatic cause the juvenile delinquency. The failed family also makes someone to be more careful to choose the married partner. The tendency is being selective to choose the men as married partner. Unfortunately, this selection process constantly makes them fall into the juvenile delinquency that cause someone come into the prostitution.

The basic reason of juvenile delinquency like free sex is because of the number of the children who drop out from school. In fact, the children that drop out from the school are confused to seek the job because they have minim skill and ability so they can't work based on their talent and dream. Finally, they just become jobless. The energy of youth can't be expressed and cause the social deviation such as free sex and other negativities.

When the children have lived out and gone far away from the family. The controlling of parents toward the children to avoid the social deviation is really needed. But the parents, whose children are living out, are so hard to control their children. The most important to do if the children are living is preparing the good personality and skill and controlled by communication and consistence. If those things are disobeyed, those can cause the social deviation.

The education that is instilled for the children will help them to achieve the carrier and future. And the parents are the right one to guide the children until adult and ready to achieve their own carrier. It is important also for the parents to know about the character and the talent of their children in education process based on the children's power and strength. Education process is not only the formal education. Non formal education can be alternative to improve the talent.

The factor of the children drop out from school is not only because the economic factor that forces the children to get away from the academic. Some people dislike school because the method is not good and monotone that makes the students bored.

Besides that, the students think that they do not need to go to school because they feel so hard to understand what the teacher teach. They also think that they do not have talent in formal education. Those cause the students drop out from the school and they are more interested in working. Before someone decides to drop out from the school, usually someone already makes palling for their future like business or marriage. But for the under age children that do not have ability to work will not be able to compete in the work world. So they will be jobless that cause the social deviation.

Other considerations why the parents do not show their children's talent are because their area does not have art gallery or organization that id active in art activity and the parents also do not believe their children to live out and continue the art non formal education out of the city. So the parents let their children to grow without continuing their education.

This condition is getting worse because of lacking of the various extracurricular so the students are not interested in continuing their school. Someone who dislikes something like school, they will tend to avoid it. Finally, they will drop out from the school. The activity that they join only the class meeting agenda held after examination twice a year. During the students can't find their talent in the school, they will not have the precious activity after school.

\subsection{The Social Relationship among the Family Members of Self-employment Woman (WKM) in the House Hold}

In the case of self-employment woman or the woman that has and ever works in prostitution, the role of family is very central. One of the family roles is having the intensity of communication among the family like the activity to gather or talk about something with other family or making some jokes.

The family is not harmonious and close one another also make someone easy to believe with other people out of the 
family. Moreover the under aged children will be so easy to be deceived or potential to be the victim of Human Trafficking. Like the case of self-employment woman that do not recognize well with someone then she is invited to work in Borneo. After dropping out and getting married in the age of 13 years old and finally divorce. After 3 months of divorce, the family can't find the solution for the problem. It makes the self-employment woman is easy to believe with other people.

\subsection{The Role and Function Occupied by Each Family Members}

\subsubsection{The Function of Family Structure}

The role and function of parents in the family is definitely important in the growth of the children. The function of father as the earner of livelihood by the time goes will turn to be a mother too. This condition happens for some reasons like the demand of necessity that makes the wife help the husband to earn money. It happens also because of the rising of education financial, so the woman turns to be active to earn the addition livelihood. Moreover if the parents' income is not enough to finance the family, the role of children by the time goes also turn to be the money earner to help the family.

Unfortunately, the income of children is often utilized by the parents as the main source of income for the family. So, the result is the children will play the role as the money earner to finance the family, not only for the parents but also for the siblings. This condition will be the problem also for the children instead. The children feel that they have the financial freedom so they can be free to do everything out of the control of their parents. It is one of the causes of social deviation done by the children because the parents do not have the power to control their children.

The control of parents toward the attitude of children actually should be shown by the father. On the contrary, the father does not play his role to control his children well. Moreover, the parents of self-employment (WKM) consider that the social deviation done by the children is not including the deviation. Other failures of parents are the inability of parents to encourage their children in reaching their dream because of their failure to give the good education for their children. The dream of parents to finance the education of the children until the high education level is failed, so the children do not have the good skill in order to get the good job.

Talcott Parson states that Adaptation is the parts of structure in a structure. The system must meet the situational need that comes from outside and must adapt with the environment such the adaptation of environment with the necessities. The family of self-employment woman (WKM) gives the regulation, value, and norm for the members to teach the family members about the way of interaction with other people. The way to accept the norm and value becomes the adaptation step for individual in the family.

The adaptation process is responded well by the family especially the husband that supports and encourages his wife to be open-minded with the family and society instead to rehabilitee the psyches of his wife. It can make the wife able to struggle to adapt with her social life and do the activity normally in the society.

\subsubsection{The Cultural Role of Family}

The role of family also has the important meaning for the defense of family. The instilling of value and norm for each individual in the family determines the individual to adapt well with the family itself. It is the mirroring of how strong the foundation that has been given by the parents to avoid the children from the social deviation.

The ineffectiveness of value and norm socialization in the family becomes the indication of social deviation happened. Even the parents clearly said that their children who are pregnant is not the mistake of their children but it is the mistakes of the men. It is supported by the fact that their children are the one who finance the family and siblings.

Beside the economic factor, the social factor also influences the culture in the society and family. The culture of marriage of the under aged children still happens. It also happened in the family of self-employment woman (WKM). The marriage soon based on the social culture in that place happened for some reasons in order to avoid the free sex. While the psychological of the children is not ready yet for marriage can cause the divorce will easily happen.

\section{Conclusion and Suggestion}

\subsection{Conclusion}

The background of someone decides to be a self-employment woman (WKM) for some reasons such as the bad experience that ever happened to someone with the couple. Beside of that, the economic factor makes the woman fall into the prostitution. The rising of daily need is not supported by the worth income. It is the reason for the woman to find the solution for it by being a prostitute.

The culture of married soon that happened in the environment makes the women fall into the prostitution. Married soon under 18 years old with the psychological of the children have not been ready forces the children to be adult earlier. 
That condition makes the children disable to show their talent and willing in their young age. The result is divorce and the women will be widow in her young age.

After divorce, constantly the children do not have meaningful activity. It happened because after getting married they do not continue their school. They are also so difficult to get job because of the minim skill and ability. Finally, they merely become a jobless. After being a jobless, the youth energy that is still prima makes them share to the negativity like prostitution.

Beside of that, the inability of parents to understand the talent and skill of the children is one of the factors that make the children have the chance to do the social practice. Only few children can be developed by the formal education. Some of the children like other sectors or departments like dancing, singing, other talents that have low assumption based on the academic sector. In this case, the parents should show the talent and skill of the children. If the skill and talent is not shown well, it will make the children express it to the negativity that causes the social deviation.

Those ones should be understood by the formal education foundation. The formal education must provide the various extracurricular not only provides about the academic services but also must consider other talents or skills of the students. So, the students get the right facility tat avoid them to express it by the wrong energy.

From all the informants, all of them only graduated from elementary school. It happened because of the culture of young married in their environment and the lacking of awareness from the parents to give their children the good education. So, the prostitution practice increases in that place.

From the parents' role side shows that the parents' role to earn the livelihood turns to be changed by the children. The function to earn money does not become the function of parents again but the children who have the big income. That income is got from the prostitution done by the children. On the contrary, the parents that basically have the function to finance the children utilize the children to get money instead. So, the parents do not have any power to control the children by the time the income of children can be enjoyed by the parents too. It looks like the exploitation of children to finance the family.

The social controlling toward the children becomes the role of parents. One of them is the instilling of value and norm that is socialized by the parents to the children. So, the children are able to adapt well in the environment. This failed function that makes the children fall into the social deviation. The decreasing of value and norm that happens in the family disturb the growth of children and the acceptance in the society.

Based on the description above, it results that the proposition in this research, such as:

1. The urgent economic factor and necessity makes someone to be the self- employment woman (WKM)

2. The husband's income can't meet the family need makes the women try to help by working as the selfemployment woman (WKM)

3. The prostitution is the job chosen as the effect of low education, so they do not have other skills.

4. The disappointment toward the husband because of divorce and making affair finally makes the women work as the self- employment woman (WKM)

5. The family relationship that is not close to one another makes someone fall into the prostitution easily.

\subsection{Suggestion}

The socialization toward the instilling of value and norm firstly done is from the growth of children in the family. If the instilling of value and norm in the family is failed, it will disturb the adaptation of children in the environment out of the family. The instilling of value and norm is the priority in educating the children because it can determine the attitude and practice of children in doing everything.

The role of parents should be maximal as the money earner and as the control toward the family attitude. It is important to do in order to avoid the children from the norm and value deviation in the society.

The education foundation should be maximal in giving attention to the children's talent and skill not only improving the academic but also improving the various talents of the children. Because only few students can be superb in academic but they are superb in art and sport.

Beside of that, the culture of young married should be avoided. The government should be more selective to give the license of marriage for the under aged children. The control of government, in this case is the ministry of religion, is clearly needed remembering that those cases constantly happen. 


\section{References}

Bahtiar, R., \& dan Purnomo, E. (2007). Bisnis Prostitusi, Profesi yang Menguntungkan, Yogyakarta: PInus Books Publisher.

Bungin, B. (2010). Penelitian Kualitatif: Komunikasi, ekonomi, Kebijakan Publik dan Ilmu Sosial Lainnya. Jakarta: Kencana Premana Media Group.

Creswell, J. W. (2013). Research Design : Pendekatan Kualitatif, Kuantitatif, dan Mixed. Yogyakarta : Pustaka Pelajar

Indrawati, E., \& Sri, D. (2014). Profil keluarga Disfungsional pada Penyandang Masalah Sosial di Kota Semarang. Jurnal Psikologi Undip, 13(2), October 2014, 120-132.

Irwan, A. (2011). Seks, Gender dan reproduksi Kekuasaan, Yogyakarta : Tarawang Press.

Kadir, H. A. (2007). Tangan-tangan Kuasa dalam Kelamin. Yogyakarta: Insistpress.

Krisnatuti, D., \& Husfani, A. P. (2012). Gaya Pengasuhan Orang Tua, Interaksi Serta Kelekatan Ayah-Remaja, dan Kepuasan Ayah. Jurnal Ilmu Keluarga dan Konsumen, 5(2), August 2012, 1907-6037.

Nurastuti, W. (2007). Metodologi Penelitian, Yogyakarta : Ardana Media. 2007.

Ritzer, G., \& Goodman, D. J. (2005). Teori Sosiologi Modern. Terjemahan Alimandan. Jakarta: Prenada Media.

Sitepu, A. (2004). Dampak Lokalisasi Prostitusi Terhadap Perilaku Remaja di Sekitarnya. Jurnal Pemberdayaan Komunitas, 3(3), 172-176, accessed on $6^{\text {th }}$ June 2015.

Soekanto, S. (1986). Talcott parsons, Fungsionalisme Impertaif, Jakarta : CV. RAjawali.

Sugiyono, (2008). Metode Penelitian Kuantitatif Kualitatif dan R\&D, Bandung, Alfabeta.

Sunarti, E. (2013). Tipologi keluarga di Wilayah Pedesaan dan Perkotaan. Jurnal Ilmu Keluarga dan Konsumen, 6(2), May 2013, 1907-6037.

Sunarti, E. D. (2003). Perumusan Ukuran Ketahanan Keluarga. Jurnal media Gizi dan Keluarga, 27(1), July 2013, 1-11.

\section{Copyrights}

Copyright for this article is retained by the author(s), with first publication rights granted to the journal.

This is an open-access article distributed under the terms and conditions of the Creative Commons Attribution license which permits unrestricted use, distribution, and reproduction in any medium, provided the original work is properly cited. 